\title{
IMPLEMENTASI LOAD BALANCING MENGGUNAKAN ANTRIAN ROUND ROBIN DENGAN STUDI KASUS E-SHOP
}

\author{
Danang Haryo Sulaksono ${ }^{1,}$ Arnold Reza Giovanni ${ }^{2}$, \\ ${ }^{1,2}$ Jurusan Teknik Informatika, Fakultas Teknik Elektro dan Teknologi Informasi \\ Institut Teknologi Adhi tama Surabaya \\ Email : danang_h_s@itats.ac.id, arnoldreza27@gmail.com
}

\begin{abstract}
Along with technological developments, the number of uses of web services is increasing. This causes popular websites to have high amounts of traffic. One of the popular websites is e-shop. The problem faced is when certain activities or events in e-shops can also cause an increase in the amount of web traffic of an org anization. One solution to deal with these problems is to use a reliable server with high performance. Another solution that can be applied is load balancing technology. Round robin algorithm is the simplest and most widely used algorithm by load balancing devices. Therefore a web was created to implement load balancing using round robin queues with e-shop case studies. The testing process in this study was calculated using QoS testing consisting of four parameters. The first, throughput is calculated and produces a value of $0.00241841 \mathrm{kbps}$. Second, the delay obtained from the calculation results is $6.086161 \mathrm{~ms}, 0.010741 \mathrm{~ms}$, $6.069903 \mathrm{~ms}$, and $6.069903 \mathrm{~ms}$ classified into very good categories for the use of transactions on web e-shops. Third, jitter obtained from the calculation result is $-0,000541933 \mathrm{~ms}$ which is classified into a very good category for the use of transactions on the e-shop web. Finally, packet loss obtained from the calculation result of $0 \%$ is classified into the very good category for the use of transactions on e-shop webs.
\end{abstract}

\begin{tabular}{|c|c|}
\hline Article History & ABSTRAK \\
\hline $\begin{array}{l}\text { Received 2020-08-14 } \\
\text { Revised 2020-08-26 } \\
\text { Accepted 2020-09-02 }\end{array}$ & \multirow{3}{*}{ 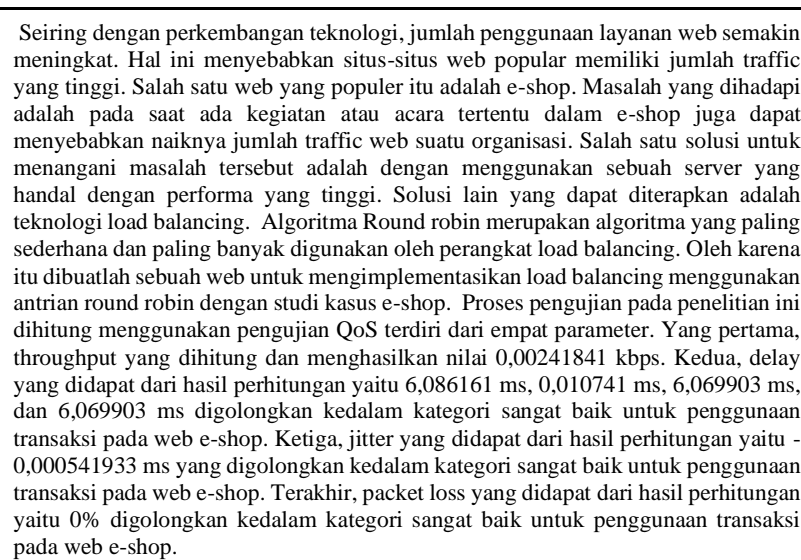 } \\
\hline Key words & \\
\hline $\begin{array}{l}\text { Load Balancing, Round } \\
\text { Robin Algorithm, QoS, E- } \\
\text { Shop }\end{array}$ & \\
\hline
\end{tabular}

\section{PENDAHULUAN}

Seiring dengan perkembangan teknologi, jumlah penggunaan layanan web semakin meningkat. Hal ini menyebabkan situs-situs web popular memiliki jumlah traffic yang tinggi. Salah satu web yang populer itu adalah e-shop. E-shop merupakan sarana penjualan, pembelian, dan pemasaran barang atau jasa melalui sistem elektronik seperti web.

Masalah yang dihadapi adalah pada saat ada kegiatan atau acara tertentu dalam e-shop juga dapat menyebabkan naiknya jumlah traffic web suatu organisasi. Peningkatan jumlah traffic menyebabkan kerja server yang melayani permintaan menjadi semakin berat. Akibatnya performa 
server menurun dan sering terjadi gangguan pada layanan-layanan web tersebut. Jika tidak di tangani, hal ini dapat mengakibatkan sistem atau situs web tersebut mati/down.

Salah satu solusi untuk menangani masalah tersebut adalah dengan menggunakan sebuah server yang handal dengan performa yang tinggi. Solusi lain yang dapat diterapkan adalah teknologi load balancing. Teknologi load balancing dapat membagi beban permintaan ke beberapa web server sehingga teknologi ini memiliki peranan penting dalam mencapai penggunaan sumber daya bersama yang efektif. Algoritma Round robin merupakan algoritma yang paling sederhana dan paling banyak digunakan oleh perangkat load balancing. Algoritma Round robin bekerja dengan cara membagi beban secara bergiliran dan berurutan dari satu server ke server lainnya.

Berdasarkan uraian diatas maka dibuatlah sebuah web untuk mengimplementasikan load balancing menggunakan antrian round robin dengan studi kasus e-shop.

Berdasarkan latar belakang yang telah dijelaskan sebelumnya, maka dapat dirumuskan permasalahan. Yaitu bagaimana mengimplementasikan metode load balancing round robin terhadap web e-shop dan bagaimana kinerja server sebelum dan sesudah diimplementasikan metode load balancing.

Berdasarkan rumusan masalah diatas maka tujuan penelitian ini adalah untuk dapa mengimplementasikan metode load balancing round robin terhadap web e-shop. Dan untuk mengetahui kinerja dari server sebelum dan sesudah diterapkan metode load balancing round robin. Manfaat yang diharapkan dapat membantu beban kerja server yang digunakan dalam pengaksesan web dengan kapasitas yang cukup tinggi dan traffic yang padat sehingga web dapat diakses dengan lancar.

\section{TINJAUAN PUSTAKA}

\section{Jaringan Komputer}

Jaringan Komputer adalah suatu sistem telekomunikasi yang didalamnya terdiri dari dua atau lebih perangkat komputer yang dirancang untuk dapat berkerja secara bersama-sama dengan tujuan dapat berkomunikasi, mengakses informasi, meminta serta memberikan layanan atau service antara komputer satu dengan yang lainnya.

\section{Web Server}

Web server adalah sebuah software yang memberikan layanan berbasis data dengan menggunakan protokol HTTP atau HTTPS dari client menggunkan aplikasi web browser untuk request data dan server akan mengirim data dalam bentuk halaman web dan pada umumnya berbentuk dokumen $H T M L$. Halaman web yang diminta bisa terdiri dari berkas teks, video, gambar, file dan banyak lagi.

\section{Load Balancing}

Load balancing adalah teknik untuk mendistribusikan beban trafik pada dua atau lebih jalur koneksi secara seimbang, agar trafik dapat berjalan optimal, memaksimalkan throughput, memperkecil waktu tanggap dan menghindari overload pada salah satu jalur koneksi. Load balancing digunakan pada saat sebuah server telah memiliki jumlah user yang telah melebihi maksimal kapasitasnya. Load balancing juga mendistribusikan beban kerja secara merata di dua atau lebih komputer, link jaringan, CPU, hard drive, atau sumber daya lainnya, untuk mendapatkan pemanfaatan sumber daya yang optimal.

\section{Data Server}

Database Server adalah aplikasi komputer yang menyediakan layanan data kekomputer atau program komputer dan memiliki fungsi sebagai tempat penyimpanan data, seperti yang ditetapkan oleh model klien-server. Istilah ini juga merujuk kepada sebuah komputer yang didedikasikan untuk menjalankan program server database. Salah satu contoh aplikasi database adalah MySQL, Oracle, MariaDB dan lain sebagainya.

\section{Algoritma Round Robin}

Algoritma Round Robin merupakan algoritma paling sederhana dan banyak digunakan oleh perangkat load balancing. Algoritma ini membagi beban dengan cara bergiliran dan berurutan dari satu server ke server lainnya sehingga membentuk perputaran.

\section{Pengujian}


Pengujian yang digunakan pada program ini adalah QoS (Quality of Services) atau yang lebih dikenal sebagai manajemen bandwidth. QoS merupakan suatu metode pengukuran seberapa baik jaringan. Qos digunakan untuk mengukur sekumpulan atribut kinerja suatu program yang telah dispesifikasikan dan diasosiasikan dengan suatu servis. Model monitoring QoS terdiri dari parameter, sebagai berikut:

1. Throughput

Throughput yaitu kecepatan (rate) transfer data efektif, yang diukur dalam bps (bit per second). Troughput adalah jumlah total kedatangan paket yang sukses yang diamati pada tujuan selama interval waktu tertentu dibagi oleh durasi interval waktu tersebut.

throughput $=\frac{\text { paket data diterima }}{\text { lama pengamatan }}$

2. Packet Loss

Packet Loss merupakan suatu parameter yang menggambarkan suatu kondisi yang menunjukkan jumlah total paket yang hilang dapat terjadi karena collision dan congestion pada jaringan.

packet loss $=\frac{\text { (paket data dikirim-paket data diterima }) \times 100 \%}{\text { paketdayang dikimim }}$

3. Delay (Latency)

Delay (letency) merupakan waktu yang dibutuhkan data untuk menempuh jarak dari asal ke tujuan. Delay dapat dipengaruhi oleh jarak, media fisik, congesti atau juga waktu proses yang lama. delay $=\frac{\text { packet length }}{\text { link bandwidth }}$

\section{Jitter}

Jitter atau variasi kedatangan paket diakibatkan oleh variasi - variasi dalam panjang antrian, dalam waktu pengolahan data, dan juga dalam waktu penghimpunan ulang paket - paket diakhir perjalanan jitter. Jitter lazimnya disebut variasi delay, berhubungan erat dengan latency, yang menunjukkan banyaknya variasi delay pada transmisi data di jaringan.

jitter $=\frac{\text { total variasi delay }}{\text { total paket yang diterima }}$

\section{METODE}

\section{Gambaran Umum}

Dalam penelitian ini diterapkan sistem menggunakan algoritma Round Robin. Dimana hal ini berguna untuk membantu beban kerja server yang digunakan dalam pengaksesan web dengan kapasitas yang cukup tinggi dan traffic yang padat sehingga web dapat diakses dengan lancar.

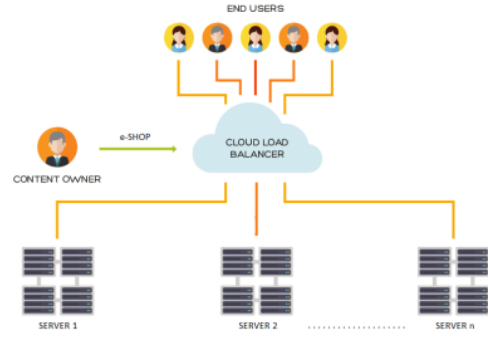

Gambar 1. Skema Perancangan Aplikasi

Gambar 1 diatas menjelaskan tentang skema rancangan load balancing round robin. Dimana client 1 , client 2 , client 3 dan seterusnya yang memiliki IP address dan ID pemain melakukan request ke server. Maka sistem load balancing akan secara otomatis untu membuat antrian secara merata kepada server yang ada dalam hal ini adalah server 1 , server 2 , server 3 , dan seterusnya. Hal ini dapat memungkinkan masing - masing server untuk menanggung beban yang lebih ringan. Load balancing adalah teknik untuk mendistribusikan beban trafik pada dua atau lebih jalur koneksi secara seimbang, agar trafik dapat berjalan optimal, dan menghindari overload pada salah satu jalur koneksi. Dapat dilakukan dengan cara memaksimalkan beberapa parameter yaitu delay, packet loss, jitter, availability dan throughput menggunakan software winbox. 


\section{Rancangan dan Pembangunan}

Tahap ini menjelaskan tentang prosedur dan proses apa saja yang akan dilakukan oleh aplikasi, alur proses, serta tampilan dasar aplikasi. Alur proses dalam hal ini berbentuk flowchart dan perhitungan manual dari metode yang digunakan. Flowchart dari sistem yang dibangun dapat dilihat pada gambar 3.2.

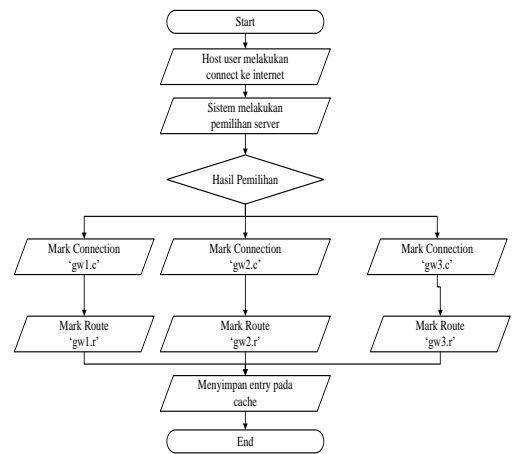

\section{Gambar 2. Arsitektur Load Balancing}

Gambar 2 diatas menjelaskan tentang rancangan arsitektur Load Balancing yang akan digunakan. Pertama pengguna diwajibkan untuk terhubung dengan internet. Lalu ketika pengguna mengirimkan request pada server maka sistem akan memilih server mana yang akan menerima Kemudian server yang menerima request tersebut akan memproses permintaan pengguna tersebut hingga seluruh request yang diminta selesai. Maka saat pengguna pertama masih melakukan transaksi dan muncul pengguna lain maka sistem akan secara otomatis memilih server yang lain yang tidak sedang memproses request dari pengguna. Sehingga pengguna dapat mengakses web secara bersamaan tanpa mengetahui bahwa sebenarnya server berbeda lah yang menanggapi mereka.

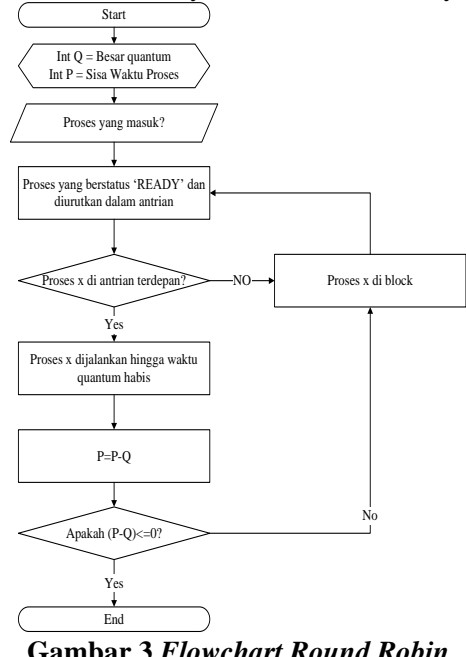

Gambar 3 Flowchart Round Robin

Gambar 3 menjelaskan tentang alur program dari algoritma round robin. Dimana diketahui Q adalah besar quantum dengan satuan integer dan $\mathrm{P}$ adalah sisa waktu proses dengan satuan integer. Ketika proses masuk maka proses akan akan diurutkan dalam antrian (ready), jika antrian sudah mencapai antrian terdepan maka proses akan dijalankan sampai waktu quantum habis, jika antrian belum mencapai terdepan maka antrian akan di block dan akan diurutkan kembali ke dalam antrian. Setelah proses antrian berjalan sampai waktu quantum habis maka nilai $\mathrm{R}$ (waktu proses) $=\mathrm{R}$ (waktu proses) 
- Q(waktu quantum), jika nilai (R-Q) kurang dari atau sama dengan 0 makan proses antrian selesai. Akan tetapi, jika nilai (R-Q) lebih dari atau sama dengan 0 maka proses akan di block dan akan di urutkan kembali ke antrian.Untuk mengetahui bagaimana cara menghitung penjadwalan Round robin. Berikut ini merupakan contoh penjadwalan Round robin.

\section{HASIL DAN PEMBAHASAN}

Pengujian sistem pada implementasi Load Balancing menggunakan antrian Round Robin dengan studi kasus e-shop ini dilakukan menggunakan pengujian QoS. Adapun parameter QoS yang digunakan dalam pengukuran meliputi Throughput, packet Loss, Delay, dan Jitter. Adapun metode pengambilan dataset yaitu :

1. Waktu pengambilan data dibatasi kurang dari 1 menit.

2. Perangkat lunak yang digunakan adalah wireshark.

3. Pengukuran QoS dilakukan pada parameter delay, jitter, throughput, dan packet loss.

4. Pengukuran dilakukan dari sisi client.

Hasil pengujian yang dilakukan pada client melalui perangkat lunak wireshark adalah sebagai berikut:

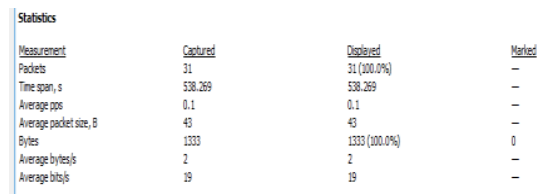

Gambar 4 Hasil Capture Wireshark

Gambar 4 merupakan hasil screenshoot dari perangkat lunak wireshark yang menjadi dasar untuk perhitungan parameter pengujian QoS.

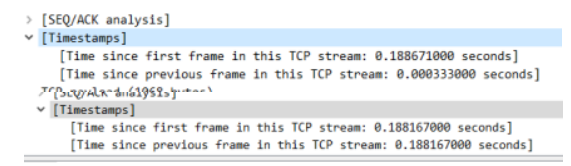

\section{Gambar 5 Hasil Capture Delay pada Wireshark}

Gambar 5 merupakan hasil screenshoot dari perangkat lunak wireshark untuk menghitung variasi delay. Terdapat lebih dari satu waktu delay dikarenakan client dapat melakukan transaksi lebih dari sekali pada satu pengujian. Dengan syarat pengujian tersebut dilakukan saat waktu quantum yang ditentukan pada algoritma Round Robin belum habis.

\section{Pengujian Throughput}

Throughput dapat dihitung dengan rumus :

$$
\text { Throughput }=\frac{\text { paket data yang diterima }}{\text { lama pengamatan }}
$$

Berdasarkan gambar 4 maka didapatkan nilai paket data yang diterima sebanyak 1333 byte dan lama pengamatan 538,269 s. Maka nilai throughput yang dapat dihitung dengan cara perhitungan sebagai berikut :

$$
\begin{gathered}
\text { Throughput }=\frac{1333 \text { byte }}{538,269 \mathrm{~s}}=2,47645693882 \text { byte } / \mathrm{s} \\
\text { Throughput }=\frac{2,47645693882 \text { byte } / \mathrm{s}}{1024}=0,00241841 \mathrm{Kbps}
\end{gathered}
$$

Sehingga didapatkan nilai throughput dari capture gambar 4 yaitu 0,00241841 kbps.

\section{Pengujian Delay}

Untuk menghitung rata - rata delay digunakan rumus :

$$
\text { Delay }=\frac{\text { Total Delay }}{\text { Total packet yang diterima }}
$$


Berdasarkan gambar 5 maka didapatkan empat waktu delay yaitu 0,188671000 s, $0,000333000 s, 0,188167000 s$, dan $0,188167000 s$. Sedangkan untuk total packet yang diterima terdapat pada gambar 4 yaitu 31. Berikut ini adalah perhitungan delay :

$$
\begin{aligned}
\text { Rata delay } 1=\frac{0,188671000}{31} & =0,00608616129 \mathrm{~s} \\
& =6,086161 \mathrm{~ms} \\
\text { Rata delay } 2=\frac{0,000333000}{31} & =0,00001074194 \mathrm{~s} \\
& =0,010741 \mathrm{~ms} \\
\text { Rata delay } 3=\frac{0,188167000}{31} & =0,00606990323 \mathrm{~s} \\
\text { Rata delay } 4=\frac{0,188167000}{31} & =6,069903 \mathrm{~ms} \\
& =6,00606990323 \mathrm{~s}
\end{aligned}
$$

Dari hasil rata - rata delay maka rata - rata delay yang didapatkan dapat digolongkan kedalam kategori sangat baik pada penggunaan transaksi web e-shop.

\section{Pengujian Jitter}

Untuk menghitung jitter menggunakan rumus :

$$
\text { Jitter }=\frac{\text { Total variasi delay }}{\text { Total packet yang diterima }-1}
$$

Total variasi delay diperoleh dari penjumlahan :

Total variasi delay $=($ delay $2-\operatorname{delay} 1)+\cdots+(\operatorname{delay} n-\operatorname{delay}(n-1))$

Berdasarkan gambar 4 didapatkan nilai total paket yang diterima yaitu 31. Sebelum menghitung nilai jitter maka hal yang perlu dihitung terlebih dahulu adalah total variasi delay : Total variasi delay $=(0,010741 \mathrm{~ms}-6,086161 \mathrm{~ms})+(6,069903 \mathrm{~ms}-0,010741 \mathrm{~ms})+(6,069903 \mathrm{~ms}-$ $6,069903 \mathrm{~ms}$ )

Total variasi delay $=(-6,07542)+6,059162+0=-0,016258 \mathrm{~ms}$

Dari gambar 5 maka didapatkan jitter dengan cara perhitungan sebagai berikut:

$$
\text { Jitter }=\frac{-0,016258 \mathrm{~ms}}{31-1}=-0,000541933
$$

Dari hasil jitter yaitu -0,000541933 maka nilai jitter yang didapatkan dapat digolongkan kedalam kategori sangat baik padapenggunaan transaksi web e-shop.

\section{Pengujian Packet Loss} dengan rumus

Packet loss adalah jumlah paket data yang hilang per detik. Packet loss dapat dihitung

$$
\begin{gathered}
\text { Packet Loss }= \\
\frac{\text { paket data yg dikirm-paket data yg diterima }}{\text { paket data yang dikirim }} \times 100 \%
\end{gathered}
$$

Berdasarkan gambar 4 maka didapatkan paket data yang dikirim adalah 31 dan paket data yang diterima adalah 31. Maka didapatkan nilai packet loss dengan cara perhitungan sebagai berikut:

$$
\text { Packet Loss }=\frac{31-31}{31} \times 100 \%=0 \%
$$

Dari hasil packet loss yaitu $0 \%$ maka nilai $p$ yang didapatkan dapat digolongkan kedalam kategori sangat baik pada penggunaan transaksi web e-shop.

\section{KESIMPULAN}

Dari hasil analisa yang telah dilakukan dapat diambil kesimpulan sebagai berikut :

1. Dari pengujian yang dilakukan membuktikan bahwa load balancing yang diterapkan pada aplikasi yang dibuat berhasil untuk mengoptimasi pada $e$-shop. Aplikasi berhasil dijalankan dan memberikan output berupa hasil pemesanan yang cepat menggunakan algoritma Round Robin.

2. Pengujian sistem yang dilakukan dihitung menggunakan pengujian QoS terdiri dari empa parameter. Yang pertama, throughput yang dihitung dan menghasilkan nilai 0,00241841 kbps. Kedua, delay yang didapat dari hasil perhitungan yaitu 6,086161 $\mathrm{ms}, 0,010741 \mathrm{~ms}$, 6,069903 ms, dan 6,069903 ms digolongkan kedalam kategori sangat baik untuk penggunaan
Commented [SA3]: Penggunaan kata-kata yan membingungkan. Jadi delay rata-rata yang mana?

Commented [SA4]: Menurut standar apa?

Commented [SA5]: spasi

Commented [SA6]: persamaan ini beda dengan persamaan 4. Rumus hanya ditulis sekali saja di persamaan 4

Commented [SA7]: standarnya apa?

Commented [SA8]: Rumus ini sudah ditulis di atas jadi tidak perlu ditulis lagi. Kalimatnya bisa diganti "dapat dihitung dengan persamaan 2" 
transaksi pada web e-shop. Ketiga, jitter yang didapat dari hasil perhitungan yaitu $-0,000541933 \mathrm{~ms}$ yang digolongkan kedalam kategori sangat baik untuk penggunaan transaksi pada web e-shop. Terakhir, packet loss yang didapat dari hasil perhitungan yaitu $0 \%$ digolongkan kedalam kategori sangat baik untuk penggunaan transaksi pada web e-shop.

\section{DAFTAR PUSTAKA}

[1] Ansharullah, Khairul. (2016). "Implementasi Sistem Load Balancing Dengan Algoritma Round Robin Untuk Mengatasi Beban Server Di SMK Negeri 2 Kudus", Buku Skripsi Pendidikan Program Studi Pendidikan Teknik Informatika dan Komputer, Jurusan Teknik Elektro. Fakultas Teknik. Universitas Negeri Semarang. Semarang.

[2] Gea, Asaziduhu. (2015). “Optimasi Turn Around Time Pada Penjadwalan Round Robin Dengan Mencari Quantum Time Optimal Menggunakan Algoritma Simulated Annealing", Jurnal Methodika, Vol. 1, No. 1.

[3] Gunawan. (2018). "Implementasi Algoritma Round Robin Pada Sistem Penjadwalan Mata Kuliah (Studi Kasus: Universitas Muhammadiyah Bengkulu)”, Universitas Muhammadiyah Bengkulu

[4] P., Yogie Ariyanto. Wicaksono, Soetam Rizky. (2017). "Sistem Pendukung Keputusan Penjadwalan Pengemudi Dengan Menggunakan Algoritma Round Robin (Studi Kasus: Zena Ttravel)", Jurusan Sistem Informasi, Fakultas Sains dan Teknologi. Vol. 6, No. 1. P-ISSN: 2303-3142. E-ISSN: 2548-8570.

[5] Putra, Rifaldi Adi. Lutfi, Helmi Faisal. (2019).“Implementasi Load Balancing Algoritma Round Robin Pada F5 Big-IP Local Traffic Manager”, Siliwangi University.

[6] Rahmana, Dany. Rakhmadhany Primananda. Widhi Yahya. (2018). "Analisis Load Balancing Pada Web Server Menggunakan Algoritme Weighted Least Connection". Jurnal Pengembangan Teknologi Informasi dan Ilmu Komputer, Vol. 2, No. 3, Hal. 915-920. e-ISSN : 2548-964x

[7] Rahmatulloh, Alam. Firmansyah MSN. (2017). "Implementasi Load Balancing Web Server Menggunakan Haproxy dan Sinkronisasi File Pada Sistem Informasi Akademik Universitas Siliwangi”. Jurnal Nasional Teknologi dan Sistem Informasi, Vol. 03, No. 02. ISSN (Print): 2460-3465 ISSN (Online) : 2476-8812

[8] Riskiono, Sampurna Dadi. Pasha, Donaya. (2020). “Analisis Metode Load Balancing Dalam Meningkatkan Kinerja Website E-Learning”. Jurnal TeknoInfo, Vol. 14, No. 1, Hal. 22-26. ISSN : 2615-224x.

[9] Triono, Gaguk. (2015). "Implementasi Load Balancing Dengan Menggunakan Algoritma Round Robin Pada Kasus Pendaftaran Siswa Baru Sekolah Menengah Pertama Labschool Unesa Surabaya". Seminar Nasional "Inovasi dalam Desain dan Teknologi."-IDeaTech. ISSN 2089-1121. 